\title{
Influences and Traditions: Wole Soyinka and the Nigerian Theatre
}

\author{
Etkiler ve Gelenekler: Wole Soyinka ve Nijerya Tiyatrosu
}

\begin{abstract}
Kenneth Efakponana ENI*
Abstract: Soyinka is a major dramatist whose work welds a lot of influence on generations of dramatists in Nigerian. A careful study of his work reveals a level of steady flow of influences that has shaped and continues to shape the literary theatre tradition in Nigeria. This paper focuses on two select works of Soyinka as a dramatist in order to highlight foreign influences that have seeped into the Nigerian theatre through his works. The paper adopts literary and critical methodologies in discussing the subject matter and in exploring the selected texts. The paper concludes that Soyinka is a major factor in bringing the foreign influences that have shaped Nigeria's theatre.
\end{abstract}

Keywords: Nigeria, Nigerian, Nigerian theatre, Nigerian literature

Özet: Soyinka Nijeryalı oyun yazarlarını etkilemiş olan en önemli yazarlardan biridir. Yazarın oyunlarına bir göz atıldığında oyunlarının Nijerya tiyatrosunu değiştirmiş olan etkilerini görebiliriz. Bu makalede Soyinka'nın iki oyunu aracıllğgla Nijerya tiyatrosuna nüfuz etmiş bulunan yabancı etkileri incelenmiştir. Çalışma konusunun ve oyunların incelenmesinde çeşitli edebi ve eleştirel yöntemlerden yararlanılmış̧ır. Çalışma, Soyinka'nın Nijerya tiyatrosunu değiştirmiş olan yabancı etkileri oyunları aracılığıyla getirmiş olduğunu iddia etmektedir.

Anahtar Sözcükler: Nijerya, Nijeryalı, Nijerya tiyatrosu, Nijerya edebiyatı

Wole Soyinka has been under attack by writers and critics of two major schools of thought that are the Neo-Negritudist apologetics for authentic traditional African aesthetics led by Chinweizu and the leftist critics of the Marxian school led by Biodun Jeyifo and Femi Osofisan.

The Nigerian Marxian Critic's fundamental quarrel with Soyinka is based on utilitarian and social responsibility theory of art (commitment) and material theory. The Nigerian Marxists are of the view of using "historical materialism" to affect change in society. A deviation from this is seen as a deliberate falsification of reality. These Marxist critics see Soyinka's perception of reality as static, mythic and unrealistic. While the Neo-Negritudist apologetics led by Chinweizu accuse Soyinka of being old fashioned, obscurantism, Euro-centrism and of using imported imagery and inaccessible language.

No matter the amount of accusations laid on Soyinka by critics, Soyinka's status as a dramatist is too well established to need further comment. However, it is pertinent to state at this point that the task of initiating a serious drama tradition in Nigeria was left to Soyinka and after the production of The Swamp Dwellers and a cut version of The Lion and the Jewel by the University of Ibadan Dramatic Society in 1958. Hence Magil (1987) comments on Soyinka's literary prowess in The Nobel Prize Winners that:

While his literary talent, his artistry, linguistic brilliance and originality is

\footnotetext{
* Lecturer, Niger Delta University, Department of Theatre Arts, kennyeni@yahoo.com
} 
extraordinary; Soyinka is especially noteworthy for his passionate commitment to his African heritage, for his successful synthesizing of it with that of other cultures and for his dedication to human freedom (100).

It is this synthesis of Nigerian culture with Western cultures, the aggregation of cultural values and theatrical forms that gives birth to new forms of influences and traditions, that is the focus of this paper.

\title{
Soyinka's Background and Artistic Philosophy
}

Soyinka is a strong supporter of the creativity school. His cry has been: Don't imitate! Create! Create! He has pioneered his own distinctive style of expression in drama. He is an iconoclast, merging old and new ideas to create distinctive ones. Despite his cry for authenticity and originality, elements of having been influenced by ideas, cultures, traditions, myth, etc which are foreign to the Nigerian cum-African base of his works abound. Gbilekaa's (1991) comment on the state of theatre practice in Nigeria under colonialism becomes relevant here when he opines that:

\begin{abstract}
The abolition of slave trade was closely followed by the introduction of Christianity and civilization in the middle of the nineteen century in Africa. The Christian missionaries introduced European values and cultures. This was in their bid to create a new social order. Colonial and Christian holocaust was closely followed by cultural genocide. The Christian missionaries in collaboration with colonialists and ex-slaves introduced a doctrinal process humanising and civilizing Africa. This colonialist effort came in form of creative literature comprising songs, music, poetry recitations and dramatic pieces which came to substitute the people's literature, songs, dances and music. The drama itself was elitist in thematic conception and the medium of communication was foreign and thus alienated the natives. The medium of communication was English sometimes injected with Latin or French expression. This to a predominantly unlettered natives carried further alienation. Thus, the thematic (social, moral or political) bankruptcy of these entertainments carried the rupture (7).
\end{abstract}

The need to redress this political and cultural colonialism gave rise to plays which portray African values to assert African and black cultural identity. These were the same conditions in the 1940's to 1960's under which Soyinka grew, studied and wrote his first plays. The period was characterised by world wars and violence. Thus, Soyinka's early plays could be seen as a reaction to this political, ideological, cultural and religious dominance of the western world.

Having had the benefit of European and African theatre traditions, Soyinka forges a unique theatre tradition between the two worlds. He juxtaposes Yoruba oral tradition and mythology with Greek tradition. But he is no less a Nigerian dramatist by his response to Euro-American influences, in his adaptation or reworking of Euripides Bacchae, Soyinka uses Ogun, his patron deity in the Yoruba pantheon as a close analogue to Dionysus for both mythic and cultural reasons.

In The Fourth Stage, Soyinka puts forward a theory of Yoruba tragedy that centres on the myth of Ogun (Yoruba god of war, iron and creativity) and Obatala (Yoruba god of creation). His essay which in itself was inspired by Friedrich Nietzsche's The Birth of Tragedy, discusses the origin of tragic feeling and the centrality of human experience in the "transitional gulf".

Soyinka's theatre is mytho-ritual, deeply rooted in the myth of Ogun, his patron god and Africa or Yoruba metaphysical, religious, philosophical world-view. His characters are psycho- 
logically identified. In his critical essay, Myth, Literature and the African World-view, Soyinka explores the Yoruba mythology that lies behind his creative works and asserts the fullness of the culture available to Africans to use in literature.

According to Ryan (1991), Soyinka was referring to a question on influences on his works in a rather elusive manner when he disclosed the following important information:

Nkosi: Have you any important authors that have influenced you most? Soyinka: This is a very difficult question for me because I am not aware of any conscious influence on my work, but I can say that if I want to aim at any particular kind of theatre, I think, however subconsciously, I might aim at Brecht's kind of theatre which I admire tremendously, just his complete freedom with the medium of theatre (196).

While aiming at the Brechtian kind of theatre, Soyinka's dramaturgy shows a marked deviation from the Brechtian by his use of myth of Ogun. Soyinka (1976) says of Ogun in The Fourth Stage: "As for Ogun, he is best understood in Hellenic values as a totality of the Dionysian, Apollonian and Promethean virtues" (141). This parallel elicitation of models is very characteristic of Soyinka's works. Soyinka is undoubtedly Africa's finest writer. According to Magil (1987) Soyinka "blends traditional Yoruba folk drama with European dramatic forms to provide both spectacle and penetrating satire" (2800). His plays have been a continuous struggle to reconcile tradition with modernization. His ideas are not altogether African, the events that shaped his vision of tragedy, which loom large in his tragic mind are not limited to Yoruba or African cosmology and they are intercontinental and universal.

Although Soyinka's early life was largely Nigerian (African), surrounded by walls of spirits, magic, ritual; while commenting on the works of Wole Soyinka against this background, Magil (1987) further reveals that

Through his extensive Western education he was able to combine his traditional African models with other literary traditions and adapted stylistic devices from such European experimental practitioners as James Joyce" (1003).

No matter what claims Nigerian (Africans) may make to authenticity in the literary genre of dramatic arts, when we confront these plays either as script or in performance, an inquiry into the Western forms which gave birth to them becomes imperative to a proper understanding of these dramas. As Jeyifo (1985) asserts:

For what we routinely encounter is that no matter how strongly they call for indigenous tragic forms, our authors smuggle into their dramas, through the back doors of formalistic and ideological predilections, typically conventional Western notions and practices (26-27).

Our main concern in the remaining part of the essay will be to uncover some of these notions and practices not just for the purpose of comparative theory and criticism, but for its cultural, ideological and political implications. As appropriate, we shall consider Death and the King's Horseman and Opera Wonyosi.

\section{Death and the King's Horseman}

Three weeks earlier, before the opening scenes of the events that took place in the play, the king of Oyo had died and it is customary that the king's horseman (Elesin Oba) must voluntarily commit suicide in order to accompany the late king to the land of the ancestors. It is on the eve that Elesin Oba is to commit suicide, that Elesin, who cannot be denied anything he requires to render his "passage" into the great beyond free of regret, that he desires a new bride. 
The colonial district officer, Mr. Pilkings, considering that the English Prince of Wales would be visiting the district and the death of a prominent chief during the period would mar his career as a district officer, decides to interrupt the proceedings of the ritual, Olunde, Elesin Oba's son who Mr. Pilkings had earlier helped to escape to England to study medicine, when he learnt of the Oba's death returns home to bury his father; when confronted with his father's failure to die in the appropriate manner, decides to take his father's place.

A careful reading of the play shows Soyinka strong sense of history. In the play, some fourteen years after the birth of the Nigerian nation, Soyinka goes back in time to events that happened in the colonial period to portray the forces at work in 1946 as the same forces at work in 1974. The inter-relatedness of colonialism to the history of Nigeria is well mirrored in the play by the presence of Mr. Pilkings and wife, and later H.R.H. the visiting Prince of Wales and the Resident.

The play was written while Soynka was at Churchill College, Cambridge. The storyline is taken from an actual historical event which took place in Oyo in 1945. However Nigerian the events dramatised in the play may be, Soyinka avails himself of his wide travels and learning to portray the Nigerian factor in the play in a universal perspective. One would be doing great injustice to the play by seeing it simply as a historical play about the Nigerian situation. The universality of its metaphysical depth is lost when viewed as such.

An understanding of the Yoruba cosmology upon which the play is built is necessary to understanding of the disruptive effects of Elesin Oba's lack of will to die. According to Bowman (1983) "The essence of this cosmology as he explains it is in direct contradiction to Christian and European emphasis on salvation" (82). Elesin Oba is conceived in the tradition of the great promethean of European tragedy; the cause of the tragedy is his one weakness: the Aristotelian tragic flaw. Thus, Elesin is not only cast in a cultural light but also as a universal being. The quality that imbues Elesin Oba's personality can be found in every culture. Like the Sophoclean King Oedipus, Elesin's sexual prowess, which up till now has been a virtue, turns to be his undoing. Iyaloja angrily rebukes Elesi:

Iyaloja: (With sudden anger). I warned you, if you must leave a seed
behind, be sure it is not tainted with the course of the world. Who are you
to open a new life when you dared not open the door to a new existence?
I say who are you to make so bold? (The bride sobs and Iyaloja notices
her. Her contempt noticeably increases as she turns back to Elesin). Oh
you self-vaunted stem of plantain, how hollow it all proves. The pith is
gone in the present stem, so how will it prove with the present shoot?
How will it go with that earth that bears it? Who are you to bring this
abomination on us? (11).

All Elesin's plea for understanding and attempt at explaining his predicament fell on deaf ears. Thus, the play is a tragedy in the Aristotelian sense. The tragedy comes about by Elesin's personal lack of will and not by Mr Pilkings interference. Jabbir (1986) opines that "What arouses pity and fear is the contrast between the manner of death Elesin had been preparing for all his adult life and the actual manner of his death, in the necessity of his death even when it has lost its initial purpose" (259). Soyinka's knowledge of the works of Euripides and Shakespeare had an influence in the plotting of this play. Suicide and conflicting code of honour which are prominent in Death and the King's Horseman is very characteristic of Shakespeare's plays. Soyinka used the play to pose a challenge to those familiar with European traditions to come to terms with Yoruba (African) metaphysical world-view, religion, and code of conduct. The challenge to European philosophy and attitude as portrayed by the debate between Mrs Pilkings and Olunde is an extension of Soyinka's Cambridge lectures in Myth, Literature and 
the Afrcan World-view. It is in preparation for this debate that Soyinka decides to cast Olunde as a young Nigerian intellectual to provide a balance and a foil for the Pilkings.

Furthermore, Soyinka explored areas of cultural overlap between Europe and Africa. At the end of the play, Olunde and Elesin are not only being mourned but there is a spirit of triumph over death that restores the dignity of the whole continent in the face of foreign challenge to its religion, culture, philosophy and ethics. Gibs (1986) in Wole Soyinka comments on the play that: "It is a dialogue with Europe - and by extension, with America - rather than a direct contribution on the debate ranging in Nigeria" (13). The debate becomes more prominent in the face of appropriation of the actual historical events. Through Olunde and the Pilkingses, Soyinka comments on events in the global community which are outside the tiny Yoruba (African) cosmology. In this reference to events outside the Yoruba cosmology, like the ranging world war and the captain that blows up himself and his ship in the service of his nation, Soyinka parallels the European view of death, honour and service to one's community with the African's view.

Death and the King's Horseman is different from Soyinka's other plays, for neither the comic or satiric purpose dominates. The reversal and recognition at the end of the play is tragic and Aristotelian. Soyinka says in the preface to the play that both history and the colonial factor are incidental to the play. However, there is a conscious effort by the playwright to present tragedy at its purest Aristotelian quality and form. The play is suffused with dramatic ritual, song, storytelling, masque, mimicry, and dance. It is a conscious effort towards the theatrical.

By its form, the play adopts European theatrical conventions. Its five-act structure and its highly elevated poetry give the play a Shakespearean quality. Gibs (1986) further comments on the play that:

Shakespeare was certainly present in the playwright's creative subconscious in Cambridge, and particularly, the Shakespeare who wrote about "bright honour" in Henry V and about suicide in the last scenes of Anthony and Cleopatra (125).

Soyinka's linguistic awareness is acute beyond the specific pre-occupation of cultural transference. He features a multilingual balance of Yoruba, English and pidgin, embracing the whole complex scale of West African linguistic relationships. With this balance, he portrays a certain sensitivity of the sociolinguistic relationship between all three, switching from one to the other and blending as his art requires. Take for instance Amusa's close imitation of English (Pidgin English) and Mr and Mrs Pilkings Queen's English:

Amusa: Sir, it is a matter of death. How can man talk against death to a person in uniform of death? Is like talking against government to person in uniform of police. Please sir, I go and come back.

Pilkings (Roars): Now! (Amusa switches his gaze to the ceiling suddenly, remains mute).

Jane: Oh Amusa, what is there to be scared of in the costume! You saw it confiscated last month from these Egungun men who were creating trouble in town. You help arrest the cult leaders yourself. If the juju didn't harm you at the time how could it possibly harm you now? And merely by looking at it?

Amusa (Without looking down): Madam, I arrest the ringleader who make trouble but me I no touch Egungun. That Egungun itself, I no touch. And I no abuse am. I arrest the ringleader but I treat Egungun with respect (25).

And also in Act III, the women broke into singing a song in Yoruba. "Tani l'awa ol' ogbeja? 
Kai! A l'ogbeja: Omo kekere l'ogbeja" (40). It is difficult to conceive the victory of the women over Amusa and his men could be better celebrated to convey its true meaning and import. Soyinka is one writer who reminds us of the fact that language cannot be divorced from the total culture which carries it. Experience shows that attempts to adapt the English language to reflect the deep feelings of the Nigerian experience reflect the limitations of such endeavour. According to Ayo (1983),

With Soyinka's plays generally, the influence of any indigenous language lies deeper still below the surface. The fusion of such influences into the medium of English seems complete and it is revealed more in the form of allusion than in syntactic and lexical manipulations. It is obvious a more difficult task to pick out linguistic Nigerianisms in Soyinka's plays (34).

Soyinka's language in his plays is impenetrable, hence he is generally considered as Nigeria's most difficult writer of English expression. This difficulty arises from Soyinka's mastery of the English language as a medium of communication. It is with this kind of Soyinka's mastery and the multi-linguistic nature of Africa that Ayo (1983) in "The Linguistic Factor in Literature" seems to see no hope in African literature in African language.

Still on Soyinka's language, Oko (1992) in The Tragic paradox: A study of Wole Soyinka's and His Works opines that:

Though Soyinka has shown remarkable originality, it must be said that he belongs to the radical British and European traditions. His familiarity with major European drama is clearly evident in his works. His association is not accidental, it was the result of and literary grooming at Ibadan and Leeds and his stint as script writer in Britain. Since he was one of those destined to create modern African literature south of the Sahara, there was not much to study as a discipline, so his literary training was a fair of classical and modern literatures. Thus a lot of what can be said to be Soyinka's theatre falls within the European tradition of age from the point of view of a world vision (8).

In the early plays, Soyinka discards the descriptive attitude to language in favour of the poetic approach. The level of interaction in language is wider than African.

The earlier critic's assumption of the theme clash of culture in Death and the King's Horseman is misleading. This is due to the fact that the play came out during a period of cultural nationalism in Africa and pursuit of cultural parallelism was a fashionable one. In addition to this, most critics of African literature in English and French at the time were convince that poetry was concerned with the universals rather than with local events of history and politics, and the tiny Yoruba cosmology as they perceive it then. An interpretation which is totally Western informed not to give credence to the Yoruba philosophical system which Soyinka was propounding. One does not need stiff lectures to know that politics and culture are profoundly interwoven. Yoruba cosmology as is with mother Africa is emerging as a political and ideological battle field of what is and what is not. Culture has been a political issue; class and religious contention, and the question of social identity characterised this era of Soyinka's struggle.

In the play, Soyinka uses dance as the movement of transition. He uses Elesin Oba's dance of protest of the women's neglect of his well-being which is purposeful, graceful and regal to contrast with the western ballroom dance that is purely entertainment. The play is thus written with the purpose of bringing into focus authentic values of African world-view and a drama- 
tization of Soyinka's arguments propounded in his ritual essays. It is a dramatization or reenactment of archetypal Ogun breaking through the chthonic realm (ritual passage) to bridge the gap between the living, the dead and the unborn. Thus, Ogun (Elesin) is equated to the Greek God Dionysus (Oedipus). Yoruba tragic drama, according to Soyinka, is the re-enactment of Ogun in conflict with cosmic spirits in the gulf of transition.

Soyinka's philosophical treatment of Elesin's struggle to gain control of the will-power and death in the play poses a challenge to western belief and philosophy of death. Contrary to western philosophy of death as a necessary end and a mystery beyond human interpretation an control, in Soyinka's drama and philosophical reasoning it is perceived as an opening of a new world, a continuation of the chain relationship between the dead, the living and the unborn:

\section{Iyaloja: ... Who are you to open a new life when you dared not open the} door to a new existence? (69).

Soyinka further contrasts the Western philosophy of individual salvation with the African (Yoruba) philosophical world-view of the death of the hero as the salvation of the community communal salvation. Towards the end of the play, the philosophical reasoning became the subject of Iyaloja and Mr. Pilkings tense and heated exchange. There is a deliberate juxtaposition of the Western and African philosophical reasoning and world-views.

Aesthetically, Soyinka's characters moved, danced, and are costumed as Africans with a European frame-work. Apart from movement, dance, costuming, and the particular circumstance of his existence, which makes Elesin Oba for instance African, Elesin Oba is an embodiment of the oedipal spirit. Soyinka did not succeed in creating a total Nigerian (African) character, but an African with European traits. Elesin Oba ranks equal to the highly literate heroes of European tragedy. Thus there is a continuous movement from the African into the European world and back again into the African in the play. Take for instance the highly mythopoeic and Shakespearean language at the beginning of the play and the totally subdued Elesin at the end of the play with his prosaic language.

Elesin occupies a Christ-like messianic role in the play. He is the mediator and the passage between the three realms of existence (The world of the living, the dead, and the unborn). Just as Jesus Christ said of himself in John 14:6 "I am the way, the truth, and the life; no man cometh unto the father but by me" (The Holy Bible, KJV). Jeyifo (1985) comments on Iyaloja testimony of Elesin's Christ-like calling thus:

The play presents a moment of negativity when the contradictions in our societies at the level of psychic and spiritual disjuncture, are revealed and probed. Soyinka's tragic issues in the play, the referential representativeness of his tragic hero plus the ideological underpinnings of these structures, are all to be grasped at this level of the collective psyche and spirit of a whole continent... (31).

Thus, Death and the King's Horseman is to be understood in a universal perspective as exemplifying Wole Soyinka's argument in The Fourth Stage.

\section{Opera Wonyosi}

As has been noted above, the complex circle of Euro-American literary influence on modern literary drama in Nigeria has continued. The tradition of adaptation, transposition, abridgement, reworking, etc have also been carried over from Euro-American dramatic literature to modern Nigerian literary drama of English expression.

Opera Wonyosi had its debut performance on the $16^{\text {th }}$ of December 1977 at the occasion of University of Ife's convocation ceremony (Now Obafemi Awolowo University, Ile-Ife). The 
play which is a transposition of two European plays: Bertolt Brecht's Die dreigroshenoper (The Three Penny Opera, 1928) which in turn is an adaption of Beggars Opera (1728) by John Gay. The three plays are satire on different levels. While Opera Wonyosi is a satire on the Nigerian society of the late 1970's oil boom generation and it lacks the metaphysical depth of Soyinka's other plays like The Road (1965) and Death and the King's Horseman (1975); Brecht's The Three Penny opera is a satire aimed at the bourgeois and the capitalist society of his day. It parodies the bourgeois morality and hypocrisy of a materialistic society. Gay's Beggar's Opera on the other hand, also attacks the Italian grand operas of the 1720's and the bourgeois societies that patronises these operas.

Soyinka's The Bachae of Euripides and Opera Wonyosi have been commented upon by drama critics and scholars as an adaptation and it is a generally agreed conception that Soyinka succeeded in Africanising these plays to the extent that he gave them a deeper dimension and complexity, radically transforming these plays. However, there is still the question of how successful Soyinka's transformation has been.

In some places, Soyinka's adaptation of the Three Penny Opera follows Brecht's play slavishly. He has not been able to transform Brecht's play totally as Brecht was able to transform Gay's Beggars Opera. Lindfors (1981) comment on the work when he states that "Soyinka seems content to pour local palm-wine into European receptacles rather than devise new containers for home-brewed spirits" becomes relevant (23). With Opera Wonyosi, Soyinka describes in vivid terms rustic post-civil war oil boom and Naira-mania in Nigeria and in more general terms, Soyinka's summation of happenings in Africa.

The play was written in 1977 and set in the Central African Empire of Banqui. Emperor Boky in the play is a satiric representation of Jean-Bedel Bokassa, who, after serving in the French army organised his country's army and became the Prime Minister of the Central African Republic. He declared himself life president in 1972 and a few years latter was crowned Emperor in an extravagant ceremony. Adeniran (1994) in The politics of Wole Soyinka describes the event thus:

\section{The crown was made of 124-carat diamond while the two tonne throne was made of gilt bronze. More than 2,000 guests were invited from abroad to witness the vainglory of an African buffoon unequalled in depth of idiocy, vulgarity and monstrosity - a disastrous phenomenon! (71).}

In Wonyosi, the new names introduced do not necessarily signal a change in characterisation. For example, Jonathan Anikura possesses the same characteristics as Jonathan Peachum and his wife De Madam, plays the same part as Mrs Cilia Peachum in Gay and Brecht's. The new characters introduced by Wole Soyinka are: a military man, Colonel Moses; the University Academic Professor, Bamgbapo; a lawyer, Alatako; a media man; and a Dee-Jay who doubles as a master of ceremony (M. C.). These are mere representatives of various professions. The M. C. usurps the position of the street singer in The Three Penny Opera. The inflated character of Bokassa easily recognisable as Emperor Jean-Bedel Bokassa of the Central African Republic. His imperial coronation serves the same purpose for the Queen's in Brecht's plot. Iji (1991) is of the view that "Like Brecht's Macheat, Soyinka's Macheat is however a Faustian figure who is an armed bandit, but squeamish of bloodshed" (170). The character structure within the play remains the same.

The plotting of Wonyosi is a carryover of Brecht's plot. The materials are organised virtually into the same organisational pattern and sequence of The Three Penny Opera. Soyinka's play like his predecessor's found the powerful, the low, the rich and the poor quilty of corruption. All three plays end happily.

Apart from the mere fact that the two playwrights (Brecht and Soyinka) use music to 
achieve alienation effect in the two plays, there is something metaphorical about the title of the plays as operas. This might be that the society in each of the playwrights setting is unconsciously dancing to some sort of unheard or undeciphered rhythm. Lindfors (1981) again comments on Soyinka's use of music in The Begging Question in Wole Soyinka's Opera Wonyosi thus:

The songs Wole Soyinka used in Opera Wonyosi came from a variety of sources, hardly any of which were African. He grafted new words into well-known Euro-American tunes, much as Gay has done with English airs in The Beggars Opera. For instance, he borrowed Curt Weill's music for "Pirate Jenny" in a later scene. Similarly, the English ballad "Who Killed Cock Robin?" Other melodies recognisable from Soyinka's lyrics include such popular favourites as "The Saint Louis Blues" and Donald Swart's "At the Drop of the Hat" and at least one Nigerian "Highlife" tune but there was no evidence that any traditional African song or indigenous musical instrument were utilised. Musically, Opera Wonyosi was an eclectic medley (25).

Like Brecht, Soyinka's dramatic pre-occupation in the play is that man, like the world in which he finds himself is in a constant process of becoming rather than doomed to stasis or unchanging and unchangeable destinies. Both dramatists do not see Macheath's crimes as worse that those crimes committed by the bourgeois and the highly placed government functionaries. Soyinka, like Brecht, deliberately refused to align with a clear cut Marxist or capitalist philosophy, but rather, the two plays portrayed man's filthy approach to survive in a filthy environment. Hence at the end of the play, the audience find it difficult to pitch camp with any of the philosophies or ideologies and identify with any of the characters in the plays. Both plays end in quandary as to the fate of the society whose criminals are given the go-ahead to operate.

For the setting of the play, Soyinka searched for an equivalent environment with Brecht's Soho and Whitechapel setting and he found it in the Nigerian quarters of the Central African Republic in Banqui. Though the setting is Nigerian, the whole spectrum of issues and the orientation given to these issues makes the play have a universal dimension, thus further moving it towards Europe and America more than Africa. The setting shows Soyinka's pre-occupation with universal issues rather than concentrating on Nigeria or Africa. Lindfors (1981) also states of that "Opera Wonyosi is a very topical Nigerian satire, but it gains much of its thrust and momentum by delivering its message in a dispensable, racy vehicle of foreign manufacture. Indeed, at times Soyinka looks more like a hitch-hiker than a trailblazer" (23). Thus aesthetically speaking, the aesthetics of Wonyosi's theatre is European.

In the play, Soyinka constantly laments about poor human conditions brought about by corruption and greed. This lament on poor human condition Achebe (1997) sees as a carryover of the sickness that is plaguing Europe. He states categorically that:

I am talking about the human condition syndrome; Presumably European art and literature have good reason for going into the phase of despair. But ours does not. The worse we can afford is disappointment (25).

Soyinka paints the picture of poor human conditions in Wonyosi almost to the point of despair. There is nothing anybody in the play could do to elevate the human condition since everybody is corrupt and perverse, except maybe Jenny, who expects nemesis one day; but nemesis from whom and for whom? Sure enough Nigeria is corrupt, but which country is not? Every country has its brand of corruption. Soyinka super-imposes foreign metaphors of corruption on the corruption of the Nigerian society, he extended it to the whole continent of black Africa and in a larger sense the entire human race in general, as the conditions he satirises 
are common to all nations although in varied degrees. He says of humanity in general in the play that "to be bribeable you've got to be imaginative. That's why the cleverest men are the most corruptible" (52). He further commented on the poor human condition through Anikura:

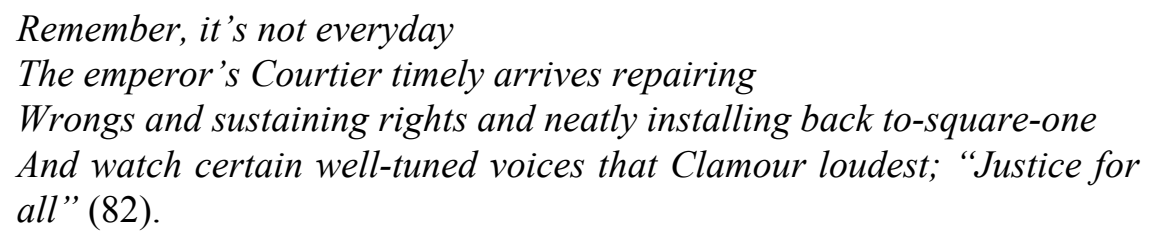

These comments on the poor human conditions are similar to those of Gay and Brecht. The influence of Christianity on Soyinka, however subtle, could be noticed in his characterisation of Prophet Jerubabel (which if one would dare to suggest is reminiscent and a carryover of the character of Prophet Jeroboam in The Trials of Brother Jero). Jerubabel which is the name given to Gideon after his destruction of the alter of Baal in Judges 6:32; unlike the Biblical Gideon who was a righteous man that delivered men from the hands of oppression, Soyinka's Jerubabel erects alters (Altars of Baal) and he is hypocritical and corrupt. Thus Jerubabel epitomizes the religious hacks which Nigeria and indeed the rest of the world is full of. A theme he has earlier explored in The trial of Brother Jero.

\section{In "the song of Jenny" Soyinka makes allusion to Biblical experience: Sodom and Gomorrah

The Biblical Sodom and Gomorrah was a whorehouse. In making this allusion, Soyinka likens what will befall Nigeria (the world) on the judgement day to the fire and brimstones which was mentioned in the account of the destruction of the cities of Sodom and Gomorrah on its judgement day and hence symbolic of God's anger. Another allusion Soyinka makes in the play is his reference to Alexender Pope in the "song of the Ruling Passion".

Structurally, the play is built on the same structural pattern as Gay's and Brecht's with music interposed within the movements where the action stops, and the actors take the songs before going back to the action. This is more of Brecht's style than of Soyinka's originality. The structure of the play heightens the alienation effect. In Soyinka's adaptation, it shocks the audience to a realisation of a sense of decaying moral values and materialistic tendencies of the class satirised in the play.

Thus, with Wonyosi, Soyinka has successfully posited that, though man, generally is evil, the society in which he finds himself makes him more vicious. Man is thus torn between the opposing forces of pessimism and optimism. The latter suggests the elimination of certain social vices for the betterment of the society, while the former suggest that man can only survive "decently" by a resourceful use of his bestial nature - a position shared by Peachum/Anikura and Macheath in the play.

\section{Conclusion}

Highly influenced by foreign factors which could be traced to his learning and travels in Europe and America, Soyinka delves into Aristotelian dialectics and aesthetics, metaphysical and psychological exploration of the human conditions. Soyinka searches for unified cosmic order in which there is harmony between the creatures and the cosmic forces. This is the main thrust of his critical essays which he dramatises in his plays.

Soyinka's theatre is thus mytho-ritual, featuring a synthesis of Western dramatic forms with 
the myth of his Yoruba heritage. The realistic movement and other ideological movement in Europe and America have also extended their toll of influence upon him. A display of Western theatrical flair which he has gained through his contacts with the West is also evident in his works.

As an adaptation of an original work, Soyinka has not succeeded in transforming Opera Wonyosi to be a truly Nigerian play much as Brecht was able to transform Gay's Beggars Opera. The cyclical influence of adaptations and reworking of preceding literary works have also been borrowed from Europe and America by the Nigerian literary artist. In the case of Opera Wonyosi, Soyinka's attempt at Nigerianising a European play has not been totally successful. Soyinka's attempt exemplifies the debt of the Nigerian stage to the Euro-American literary theatre traditions.

\section{Bio}

Kenneth Efakponana Eni lectures in the Department of Theatre Arts, Niger Delta University in Nigeria. He has published papers in reputable journals and is currently preparing for his $\mathrm{PhD}$. defence at the Delta State University. His research interest is in the areas of Performance Theory and Criticism, Theatre Technology and Culture and Theatre Interface.

\section{REFERENCES}

Achebe, C. (1997). Africa and her writers: Morning yet on creation day essays. London: Heineman.

Adeniran, T. (1994). The politics of Wole Soyinka. Ibadan: Fountain Publications.

Banjo, A. (1983). The linguistic factor in literature. Ibadan Journal of Humanistic Studies, 3, 47-69.

Bowman, R. M. (1983). Leaders and leftovers: A reading of Soyinka's Death and the King's Horseman. Research in African Studies, 14(1), 66-102.

Gbilekaa, E. T. S. (1991). Radical theatre in Nigeria: 1970-1986. Theatre Forum 2(1), 37-39.

Gibs, J. (1986). Wole Soyinka. London: Macmilan.

Iji, M. E. (1991). Understanding Brecht and Soyinka. Ibadan: Kraft Books Limited.

Jain, J. (1986). The unfolding of a text: Soyinka's Death and the King's Horseman. In Research in African Studies, 17(2), 6-21. Texas: University of Texas Press.

Jeyifo, B. (1985) The truthful lie: Essays in a sociology of African drama. London: Villiers Publishing Limited.

Linfors, B. (1981). Begging question in Wole Soyinka Opera Wonyosi. ARIEL: A Review of International English Literature, 12(3), 13-27. Canada: Morris Printing Company Limited.

Magil, N. F. (1987). The Nobel prize winners (1962-1986). New Jersey: Salem Press.

Oko, A. (1992). The tragic paradox: A study of Wole Soyinka and his works. Ibadan: Kraft Books Limited.

Ryan, B. (1991) Major $20^{\text {th }}$ century writers: A selection of sketches from contemporary authors. London: Colgate Research.

Soyinka, W. (1976). The fourth stage. In Myth, literature and the African world. London: Cambridge University Press.

Soyinka, W. (1982). Death and the king's horseman. London: Methuen. 